\title{
Clinical Trial Investigator Newsletter
}

National Cancer Institute

\section{Source}

National Cancer Institute. Clinical Trial Investigator Newsletter. NCI Thesaurus. Code C115544.

A publication that informs the investigative staff about common implementation issues, and the progress of a clinical trial. 